\title{
Original Article \\ Design history of China's gated cities and neighbourhoods: Prototype and evolution
}

\author{
Miao $\mathrm{Xu}^{*}$ and Zhen Yang
}

School of City and Regional Planning, Cardiff University, Glamorgan Building, King Edward VII Avenue, Cardiff CF10 3WA, UK.

E-mail: XuM1@cardiff.ac.uk

*Corresponding author.

\begin{abstract}
As a global phenomenon, the gating form of gated community is often understood within a general context which by and large ignores the significance of the unique historical, political and socio-cultural momentums in a specific urban context. Through a historical review of the vicissitudes of gated cities, neighbourhoods and residential compounds in China and their physical evolution as well as the social change behind them, this paper endeavours to reveal that the enclosed physical forms and organizational patterns of gated community are deeply ingrained in the Chinese history of city design. Moreover, it shows that rather than exhibiting a localized version of a global process, gated community in contemporary China has its own socio-political rationale in the making. In consequence, the ingrained tradition and unique developing trajectory have a profound impact on both the visible and the invisible characteristics of gated community in China today, while the latter has eventually distinguished itself from all its predecessors in history. Based on this review, this paper concludes by arguing that any comprehensive understanding of gated community in contemporary China can only be achieved if the significance of the historical and local socio-political context is fully appreciated.
\end{abstract}

URBAN DESIGN International (2009) 14, 99-117. doi:10.1057/udi.2009.12

Keywords: gated community; Chinese planning history; ingrained prototypes; spatial-political economic context

\section{Introduction}

Gated community is now recognized as a global phenomenon. Although much research on it has focused on general features and socio-spatial consequences (Blakely and Snyder, 1997; Webster, 2001, 2002; Low, 2003, 2006; Atkinson and Blandy, 2005; Glasze, 2005; and so on), more and more researchers have been aware of and paid attention to the local forces involved, which are regarded as substantially mediating the final outcomes of adapted gated communities in specific loci (Frantz, 2001; Sabatini et al, 2001; Wu, 2005; Huang and Low, 2007). As a result, a historical review, which is indispensable for understanding the local context, becomes one of the key approaches. However, the local forces addressed by previous historical reviews in terms of gated communities are mainly to do with housing traditions, their socio-cultural trends and the institutional-economic background. The role of city design has by and large been overlooked, though it is always a pivotal issue in the shaping of urban space in history. Therefore, this paper intends to examine the design history of China's gated cities, dissecting the ingrained prototypes of enclosed physical forms and organizational patterns in the Chinese history of city planning, especially for residential compounds. Arguing that environmental disciplines are epi-phenomena of deeper and more enduring social forces that emanate from the overall production of the material basis of life, that is, from the economy as a whole, Alexander Cuthbert develops Castells' definition of urban design ${ }^{1}$ and points out that the materialization of space as urban form is not 
arbitrary, and that the whole discourse of urban design should be built on spatial political economy (Cuthbert, 2005). This retrospective examination of the design history is therefore not only about spatial forms, but also about the politicaleconomic background of the time.

For clarity, this historical review will basically follow chronological order and be classified into three categories: the lengthy pre-1949 feudal monarchy, when walled residential quarters and introspective courtyard archetypes were sustained; the socialist period from 1949 to 1978 when gated work-compounds (danwai) came to dominate the urban landscape; and the postsocialist era after 1978 when the contemporary gated community has gradually come into being in China and gained overwhelming prevalence in the commodity housing market.

\section{The Enclosed Urban Form in Chinese Centralized Feudal Monarchy, Pre-1949}

The traditional Chinese city generally exhibited five major morphological characteristics, namely walled enclosure, axiality, north-south orientation, symmetrical layout and closed courtyard (Wu, 1993; Gu, 2001; Dong, 2004). Hereinto, both 'walled enclosure' and 'closed courtyard' indicate the long-existing tradition of walled urban morphology and introverted living patterns during over two thousand years of highly centralized feudal monarchy. While the former describes the whole urban form at the macro-level, the latter can be regarded as the elementary dwelling typology in micro-level urban areas.

\section{Strictly controlled city and walled residential wards}

Manipulated by mighty aristocratic power (Heng, 1999), Chinese cities before the Song Dynasty (960-1279 AD) had a highly hierarchical social structure, and were strictly controlled. Commercial activities were also rigidly suppressed. Tang Chang'an (618-906 AD), housing over a million people with a well-developed urban form, is the most typical and influential model $^{2}$ of this kind (Figure 1).

The strictly controlled residential pattern in Tang Chang'an, originally called $l \ddot{u} l i{ }^{3}$ was initially shaped in the ancient slave society of the Shang Dynasty, was renamed li fang in the Sui
Dynasty, and was at its height in Tang Chang'an (Dong, 2004). It also reflected and reinforced stringent social hierarchy by confining populations rigidly in their respective wards. Residential and commercial functional areas were divided into separate zones. This segregation went against not only residents' convenience in everyday life, but more fundamentally, commercial prosperity. So, when the regime went into decline in the second half of the Tang Dynasty, the government's stringent supervision over both walled residential wards and the trading system began to break down.

\section{Prosperous mercantile society and fall of ward walls}

The economic growth facilitated by long-term social stability and the revolutionary improvement in agricultural technologies in the Song Dynasty (960-1279 AD) was the decisive driving force to overthrow the previous highly demarcated and controlled urban form. On the one hand, an unprecedented growth in urban population and the specialization of urban production activities like handicrafts substantially promoted the prosperity of commercial activities, which required demolishing the physical and institutional barriers to trade. On the other hand, and more fundamentally, due to increasingly flourishing commercial activities, a progressively secular and mercantile society came into being. As a result, the ruling system dominated by aristocratic power gradually gave way to a government managed by pragmatic professional bureaucrats, who turned wall demolition into a money-making opportunity by charging for offending behaviour such as demolishing ward walls or street encroachment (Heng, 1999).

Eventually, the physical and institutional constraints on the city were officially abandoned for an open urban structure. The residential pattern of $l i$ fang was replaced by fang xiang with free movement and mixed land-use, and this pattern ran through the following thousand years until today. Fang was commonly a long rectangular residential site naturally divided by a main road and branching streets. Xiang (also called hutong in northern China) is the street connecting the dwelling units (Figure 2) in fang. It became in practice a communal linear public space with a strong sense of community for local inhabitants (Figure 3). The sense of belonging and territorial 


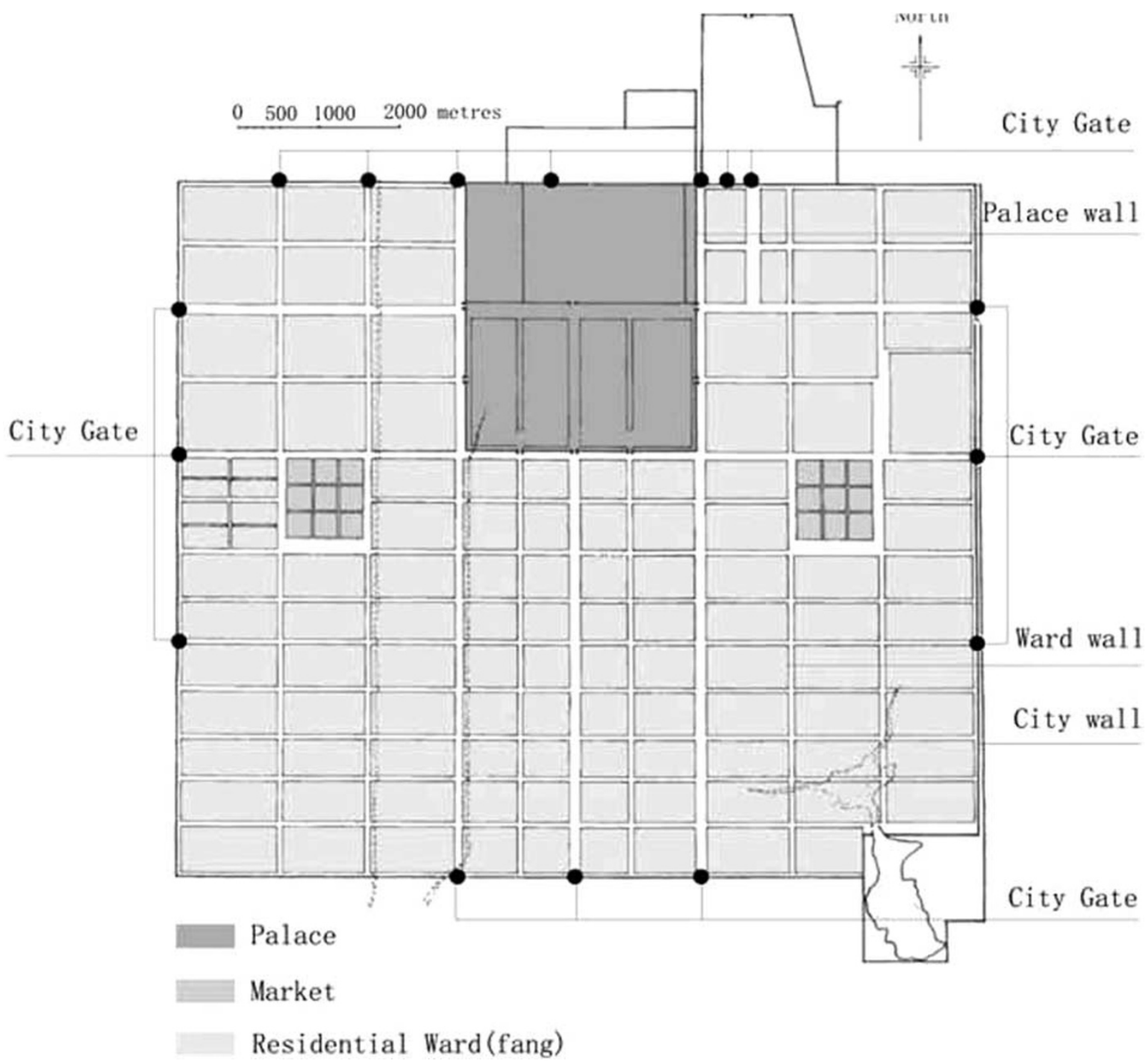

Figure 1: City map of Tang Chang'an.

Source: Based on various cartographic sources. The city as a whole was walled with 16 city gates. Within this fortified perimeter, the walled palace was located to the north. Eleven north-south and 14 east-west major streets divided the walled city into 108 fang, or wards (residential quarters), and two designated markets. These residential wards, fang, ranging from 30 to 80 hectare, were enclosed by earthen walls on the sides of rectangular precinct and connected with the outside through one or two major gates guarded by warders (Dong, 2004). Apart from the aristocrats and government dignitaries, the commoners were forbidden to pierce private gates in the ward walls to have direct access to the external streets. The residents were not allowed to leave the wards after the gates were closed from the second night watch (9-11 p.m.), unless a special permit was issued in case of an emergency, such as illness or marriage (Heng, 1999).

control became even stronger when there was a door with a nameplate at the gateway of xiang (Figure 4). Shops gathered around the gateway, serving the daily needs of local residents within a handy distance (Dong, 2004). Basically, all the streets (xiang/hutong), whether wide or narrow, were entirely accessible to the passer-by. But most streets were still continuously confronted by high blank walls of housing units, even in some bustling commercial areas (Figure 5). Hence, although the ward walls were dismantled, the wall was still an elementary component in the renewed order of the urban form, separating the private and quiet family space from the public and chaotic urban environment. It is still the wall rather than the home building itself that faces directly onto the street. Some drawings of the time show the most telling evidence of such conditions (Figure 6). 


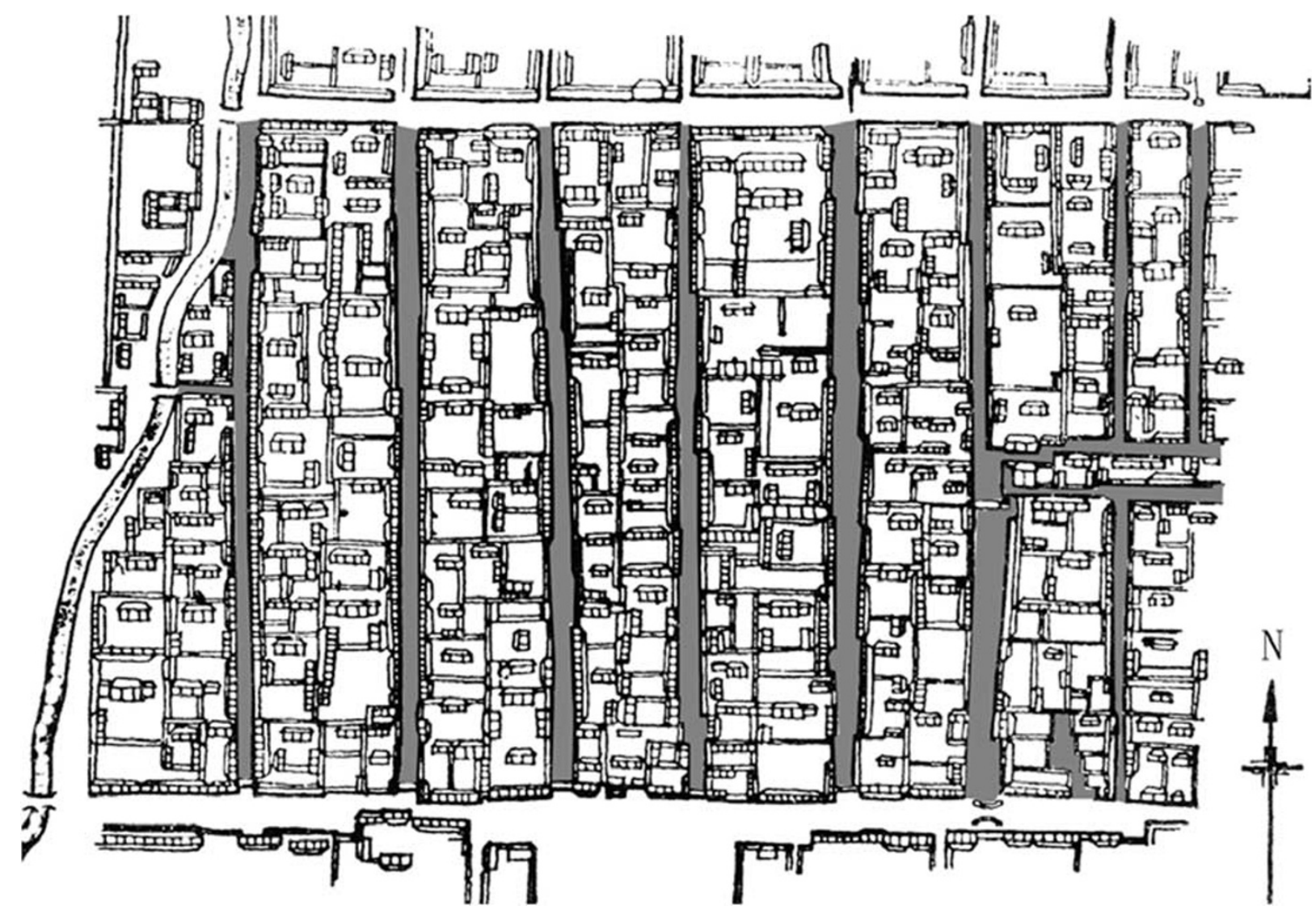

Figure 2: Typical street pattern of fang xiang.

Source: Adapted from Liu (1984).

\section{Westernized urban settlements and retained introverted pattern}

The urban transformation described above was by and large a self-evolving process based mainly on a traditional agricultural economy. It progressed very slowly in both size and form. Until 1840 when western capitalistic forces began to encroach upon Chinese territory, there were actually no modern industries and cities in China. But very soon, over 30 treaty ports were set up in the major cities along the coastline and the Yangtze River, where foreigners were not only permitted to carry out business but also allowed to build up their settlements in the leased territories (27 in all). With western urban structures and lifestyles grafted onto the indigenous residential patterns, these colonial cities experienced a drastic transformation. The pattern of li long appeared in this west-east and moderntraditional confrontation, and gradually became the dominant residential form for the mass of bourgeois citizens in the treaty port cities (Figure 7). Basically, li long was little different from the pattern of fang xiang in terms of spatial form and settlement organization, except that:

- the low-rise courtyard houses were transformed into higher density of 3- to 4-storey terraced houses with smaller courtyards at the back;

- most of the units facing the outer streets, especially the ground floor, were more open in form and often transformed into commercial or other uses;

- on each residential site, there were several clusters which were organized by a main alley and a series of branching ones in cul-de-sac style. The hierarchically arranged alleys were actually semi-private/public spaces, discouraging passing-by behaviour. This facilitated territorially based control by the local community.

This transformation shows that when traditional residential patterns were modified to have more relationship with their surroundings, like streets in modern society, the introverted housing tradition and territorial control were 


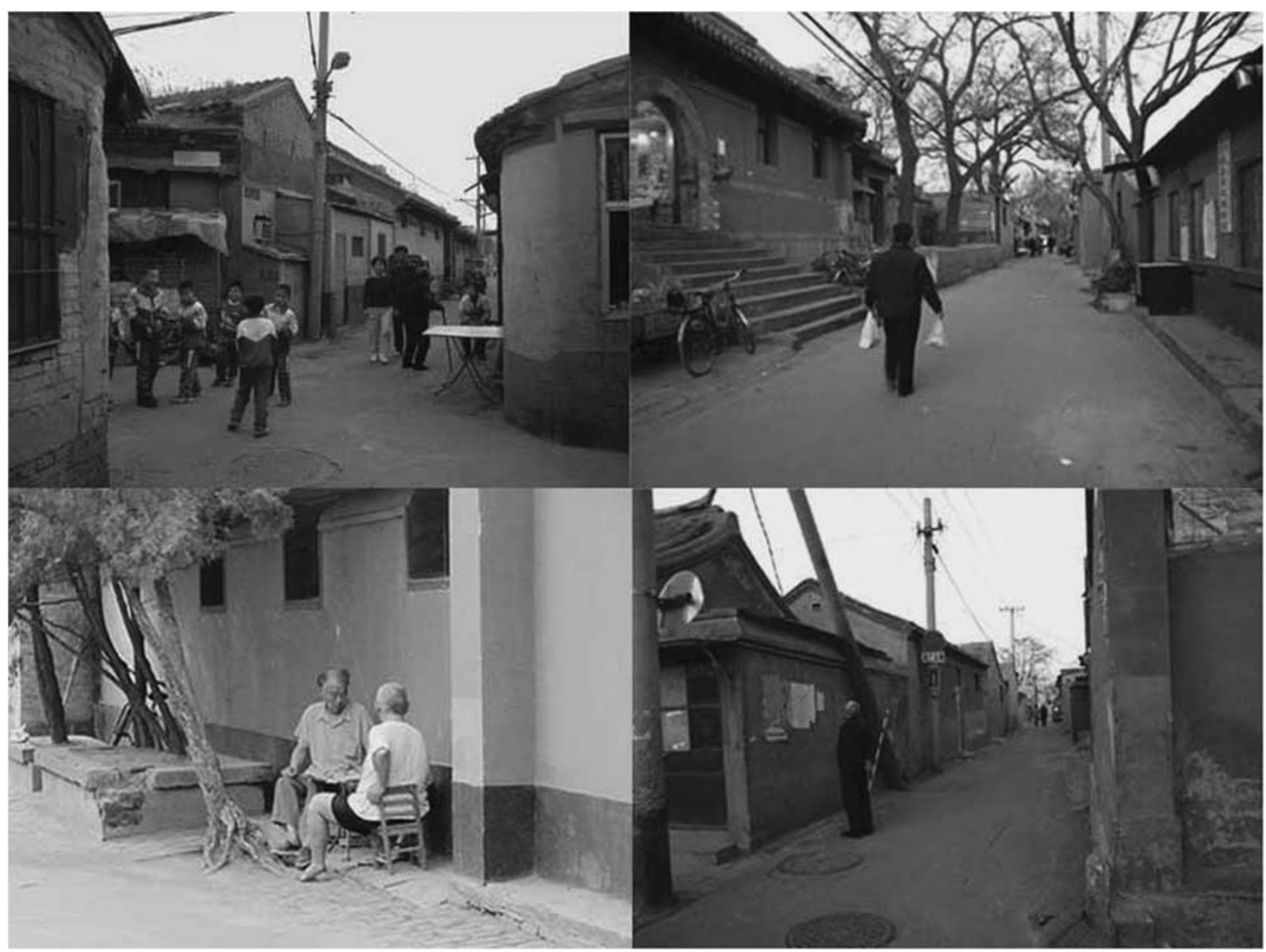

Figure 3: Diverse activities in the public linear streets (hutong) between walls of courtyard-houses, Beijing.

insistently retained and achieved by an intentionally organized residential form. Although the treaty port cities underwent rapid physical changes, the major inland and interior cities out of the reach of the colonial impact saw little change in urban form and life styles. The housing patterns in these cities continued to follow traditional lines until 1949, when the People's Republic of China (PRC) was founded, and immediately launched large-scale nationwide urban development.

\section{Introverted courtyard prototype and walled collective living tradition}

One morphological character is too evident to be ignored in the previous review of the traditional urban form and residential pattern. That is enclosed open space. This existed ubiquitously in traditional Chinese cities and especially housing compounds, although it varied endlessly in number and size with respect to the vast territory, tremendously diverse climatic conditions, and 55 disparate nationalities in China separate from the ethnic majority of Han (Wu, 1963; Knapp, 2005). The enclosed open space embodies a distinct difference in the building-space relationship of housing layout between western and Chinese traditions. Compared to the openness and accessibility of a typical western house standing in a yard or garden, the Chinese tradition inclines to internalize the open space with walls and buildings around it (Figure 8). This inward looking open space in a housing compound is named courtyard or quadrangular-yard (si heyuan) in northern China, and sky well (tian jing) in the south.

The prototype of introverted spatial organization by means of the courtyard was found at the very beginning of Chinese written history 


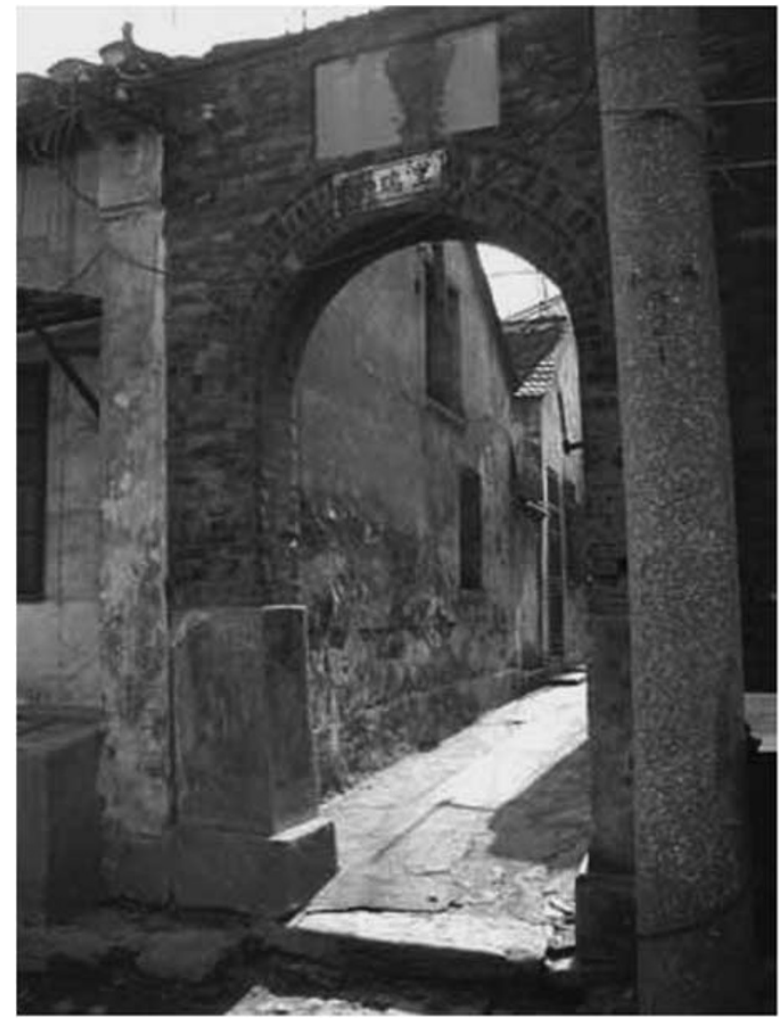

Figure 4: A door with nameplate at the gateway, a historical block in Zhenjiang.

(Figure 9), and has changed little if compared with the courtyard houses built within the last hundred years. In addition, more than an essential element of the housing compound, this courtyard prototype was so ingrained in traditional Chinese architecture that can be discovered ubiquitously in palaces, temples, gardens and other types of built environment in ancient China (Figure 10). As a basic unit of ancient urban form, it conforms to and reflects Daoist geomantic principles and Confucian ritual rules, which are recognized as the two main sets of tenets shaping traditional Chinese cities (Gu, 2001; Dong, 2004).

The courtyard embodies the Daoist views of the void-entity relationship ${ }^{4}$ and geomantic principles for living. In the philosophy of Daoism, everything should be regarded as and resemble the integrated world composed by the positive (yang) and negative (yin) substances. While buildings, the entities, form the positive structures, it is the enclosed open space, the void, which complements the negative part in composing an integrated house. The courtyard, the open space enclosed by buildings and walls, stands for the void, and is therefore the indispensable component of the house. It was regarded as the means to realize a harmonious relationship between the human and nature in the housing compound (Figure 11). In practice, the courtyard helps to provide a good microclimate by applying the different proportions of enclosed spaces in different regions with different climates. ${ }^{5}$

The proverb 'four generations under one roof' describes precisely the collective living tradition of the big Chinese family (Huang, 2006) which is descended from the same ancestor through the patrilineal line. The ingrained Confucian ritual believes that the best spatial organization of a house should felicitously respect or exhibit not only the kinship relationships between household members, but also the spatial transition between private individual spaces, the communal spaces shared by the whole family, reception spaces for guests and the outer public world. In this regard, the housing layout with a sequential series of courtyards fits in perfectly with the desired spatial hierarchies (Figure 12). Moreover, the courtyard prototype is very adaptable by endless replication to the irregular requirements of an extended family. With three or more generations living together in multiple courtyards, the housing compound for one family is actually like a small walled city (Figure 13). 'Walls with walls and, behind those walls, more walls' (Dutton, 1998).

\section{Renewed Walled City of Work Units in the Socialist Era, 1949-1978}

\section{Spatial and social outcomes of work-unit (danwei) compounds}

After the PRC was founded in 1949, the urbanization process was dominated by a socialist political framework until 1978, when the new agenda of reform towards a market-oriented economy was set up. In the initial stages, the Soviet model of urban planning was quickly taken up in China (Dong, 2004). Based on socialist ideology, the rationale of Soviet urban planning presumed that industrial production was the major function of cities. Consumption was disdained as associated with waste and the bourgeois lifestyle, so cities should be transformed into engines of production, rather than remaining sites of decadent consumption. The slogan of the time, 'Production first, livelihood second', accurately conveyed this mainstay ideology. The essentials for living would 


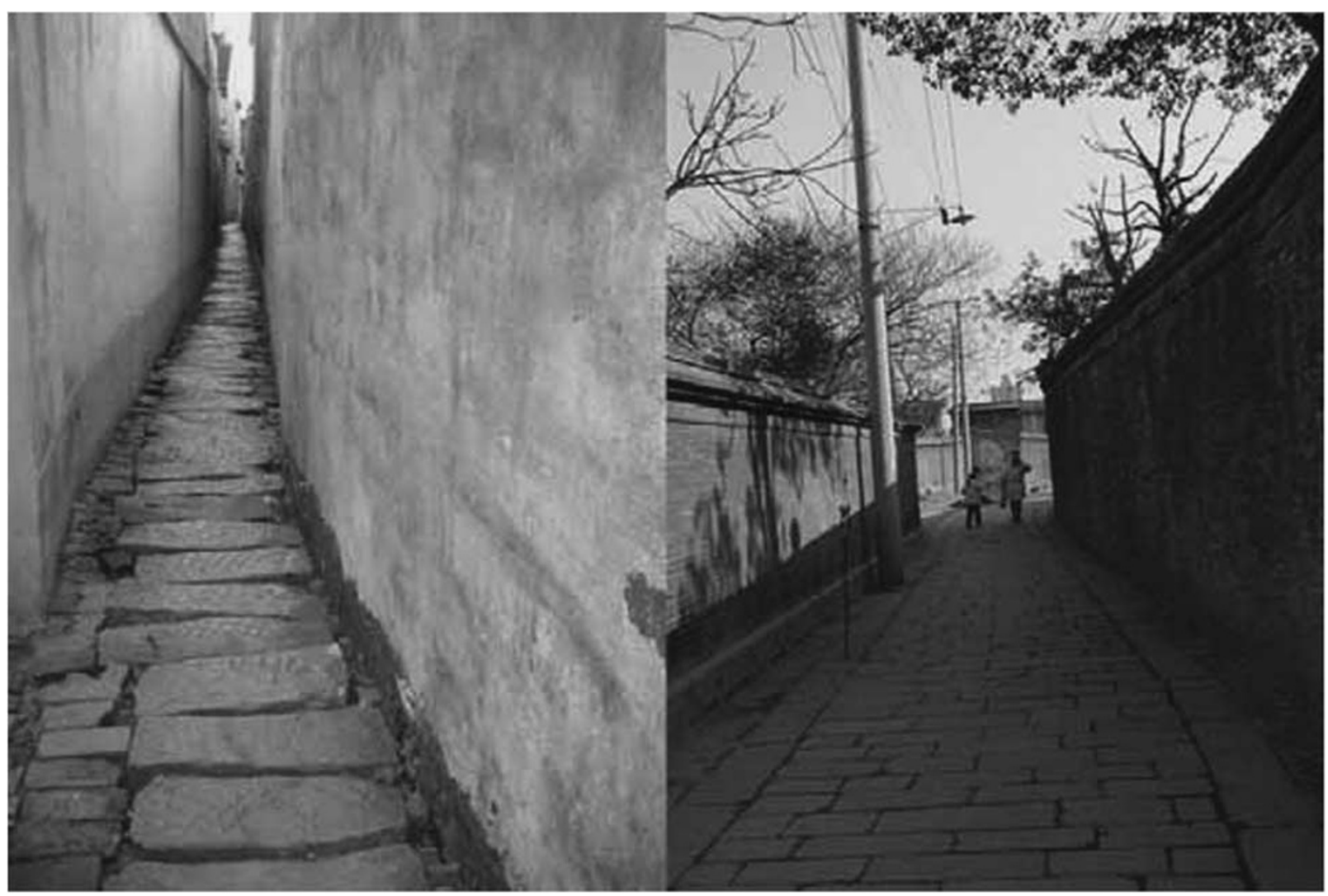

Figure 5: Streets confronted by the continuous blank walls of housing units.

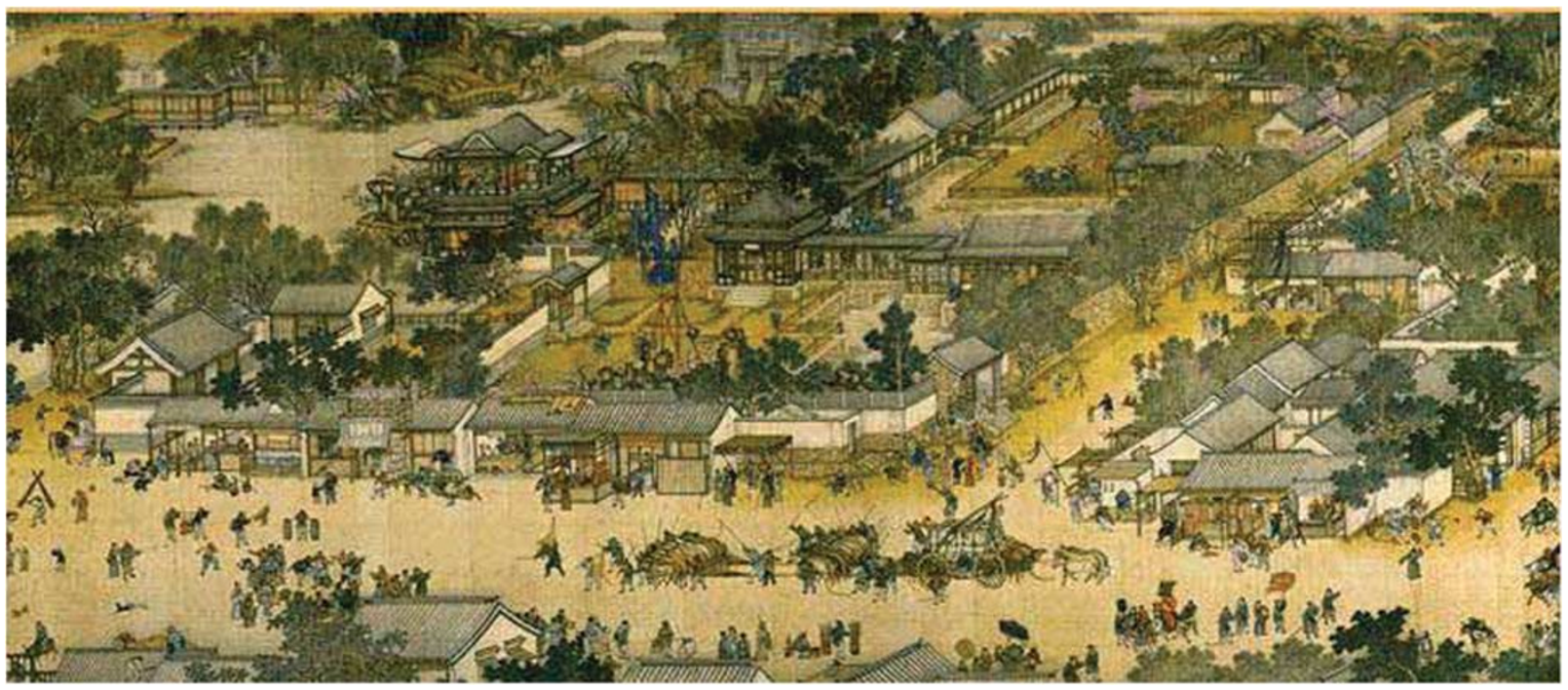

Figure 6: Walled courtyard houses in the bustling urban area with diverse commercial activities, depicted by Zhang Zeduan, the painter of Song Dynasty (960-1279 ad), in his famous drawing 'Qing Ming Shang He Tu'.

be guaranteed by the urban welfare system. Therefore, to convert 'cities of consumption' into 'cities of production', a series of policies aiming at high industrial accumulation and low consumption were put into effect with low cash wages and in-kind welfare supplements like housing. In this process, the work unit (danwei), including stateowned enterprises or other service institutions (health care, education, research or administration), appeared to be the principal entity for both 


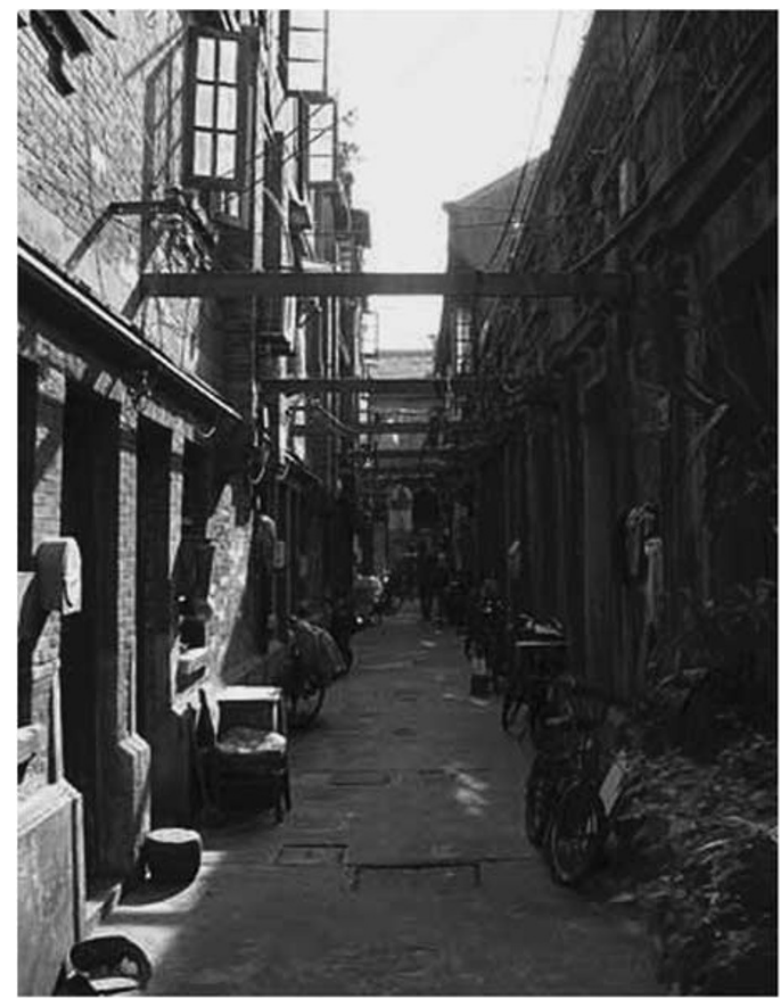

Figure 7: Vista from alleys of li long, a historical residential block in Wuhan.

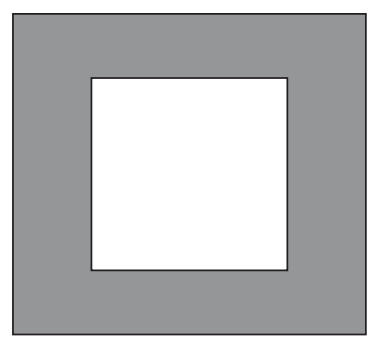

Chinese tradition: building surrounding the space

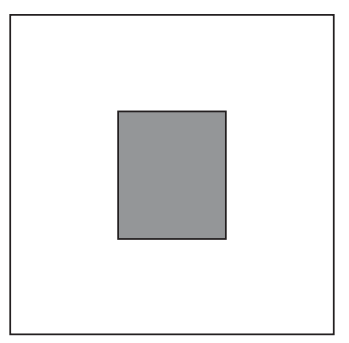

Western tradition: Building outstanding in the space
Figure 8: Comparison of building-space relationship in housing layout between western and Chinese traditions.

production and distribution in the resource allocation system of a highly centralized planned economy.

However, although Chinese institutional economy and urban planning in the socialist era were heavily influenced by the former Soviet Union, the cities went far beyond Soviet models by means of the work-unit compound, which was actually a distinctive Chinese invention. Rather than adopting the Soviet model in which residential districts were spatially separate from the workplace allowing for up to a 40 -min commute

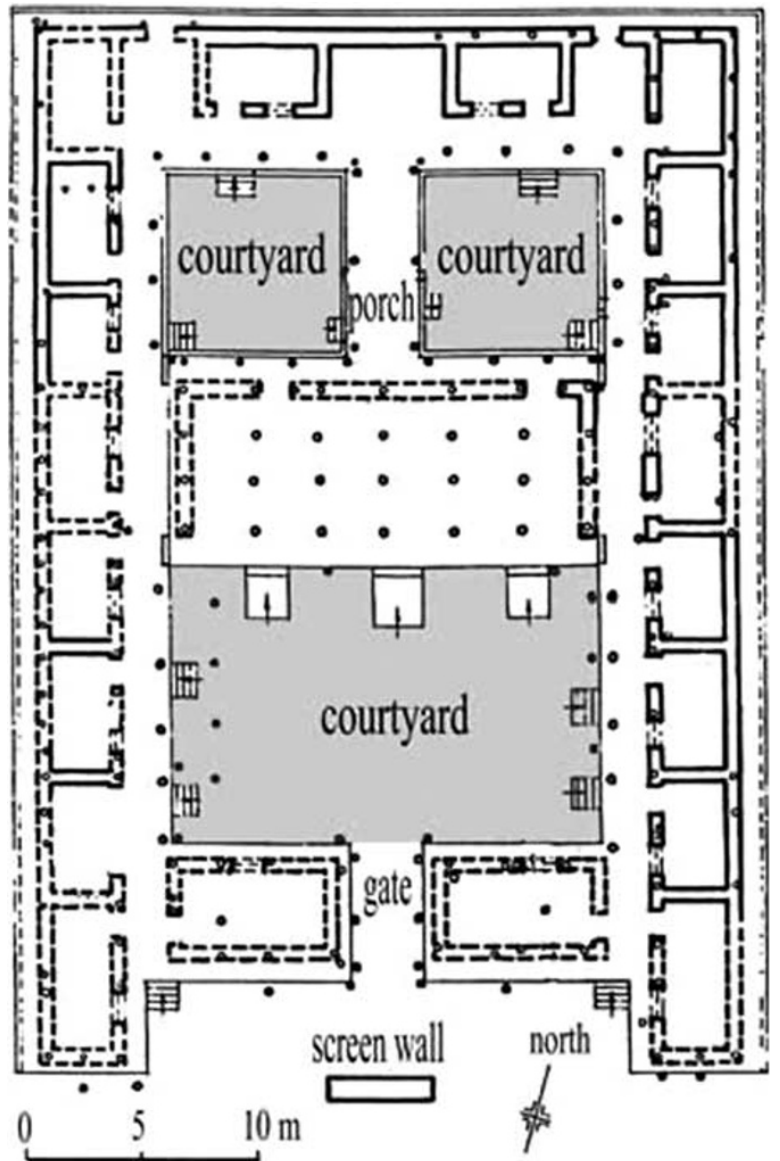

Figure 9: The earliest archaeological evidence of courtyard found in the historic site of Western Zhou (1025 BC-256 bc), Qishan, Shanxi province.

Source: Based on various cartographic sources.

on public transportation (Bater, 1980), the work unit in China attempted to integrate working and living space in close territorial proximity, combining housing, workplace and the provision of social services. This work-unit-based spatial model soon dominated mass urban development because of the power and privilege of work units in the socialist economic structure. The 'city under Mao was a relatively weak entity characterised by the dominance of the work-unit' (Cartier, 2005). Basically, work-unit compounds shared three common features in social and spatial outcomes (Figure 14):

1. A self-contained and high level of social facilities: small work units generally had canteens, social halls, clinics and public bathhouses; medium-sized units may have added nurseries, kindergartens, parks, libraries, sports fields, guesthouses and shops; large work 


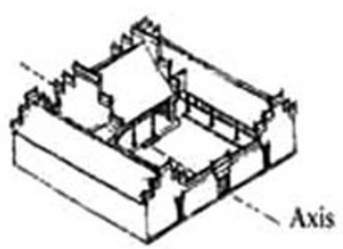

U-shape Courtyard

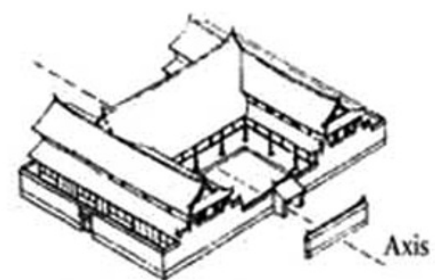

H-shape Courtyard
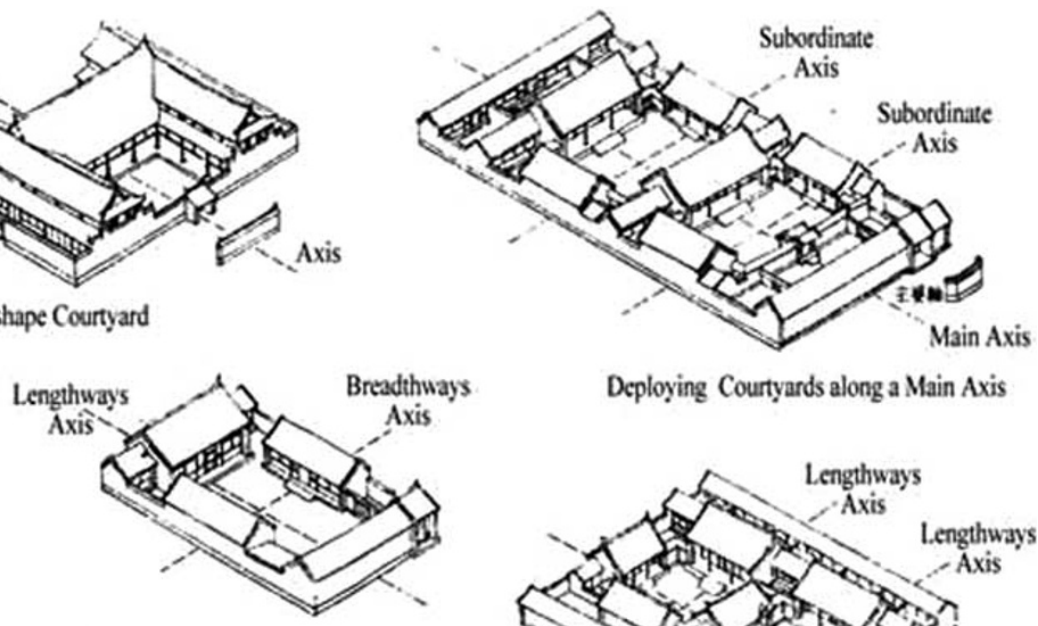

Deploying Courtyards along a Main Axis

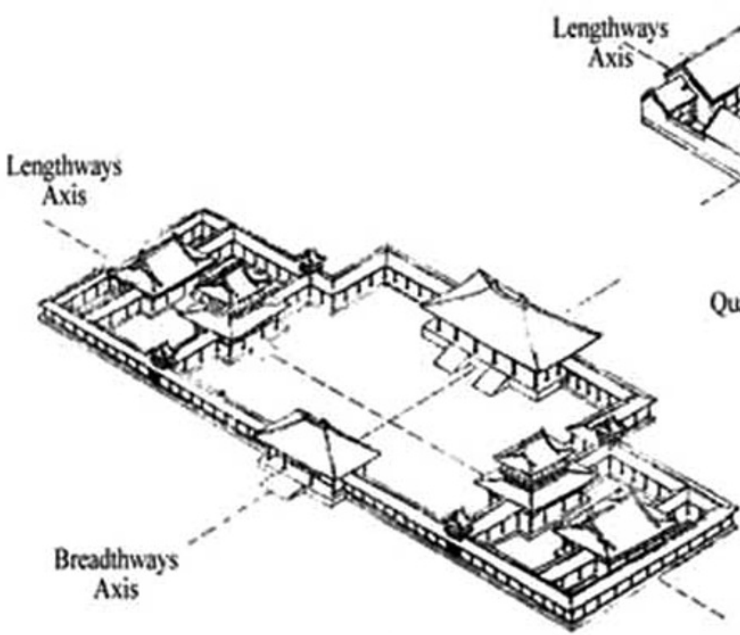

Quadrangle Courtyard

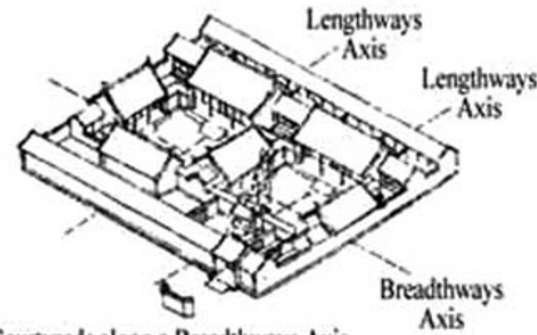

Deploying Courtyards along a Breadthways Axis

Axis

Temple depicted in the Fresco of Mogao Caves, Dunhuang

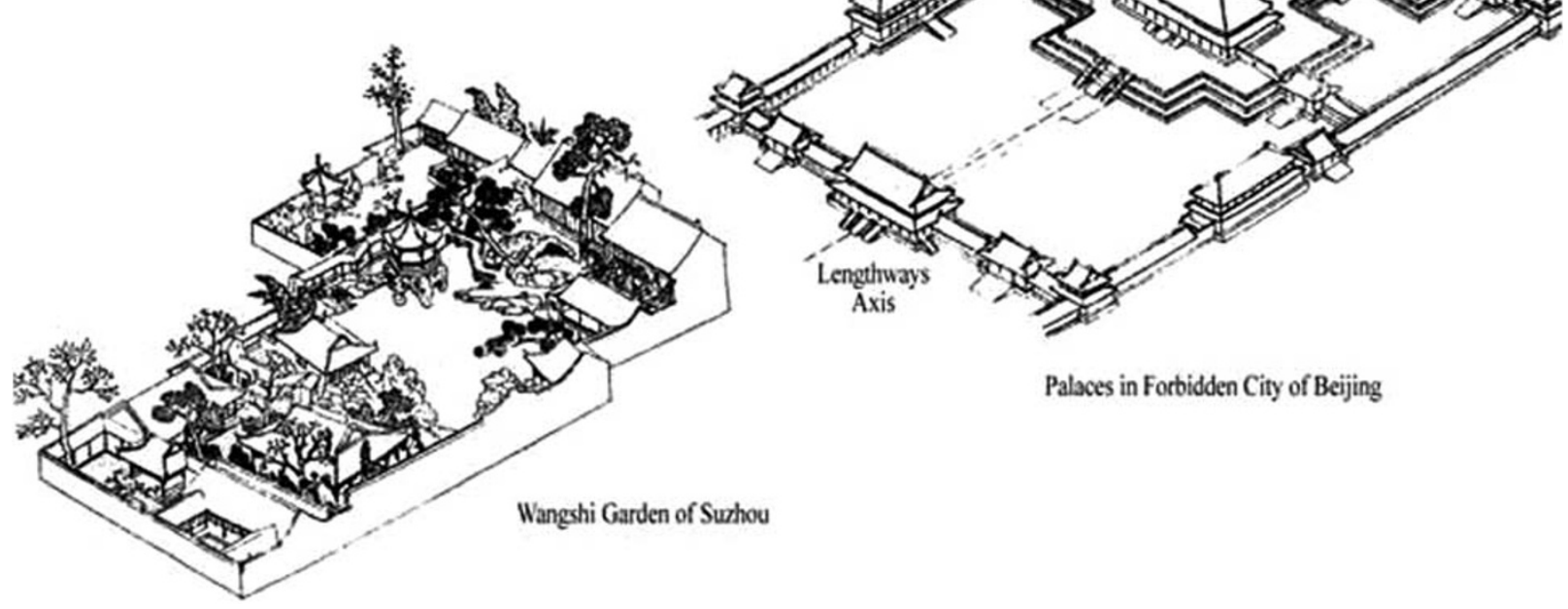

Figure 10: Enclosed courtyard as the basic element of ancient urban form. Source: Adapted from Liu (1984).

units, especially those in remote suburban or rural areas, were often so self-contained as to resemble a miniature city $(\mathrm{Lu}, 2006)$.

2. A high level of social mix and close affiliation: working and living closely in a work-unit compound, the diversity of workers and their family members in terms of age and sex fostered a high level of social mix. Furthermore, the dense network of human relationships between members cultivated by joint living and the patriarchal authority exerted by the work unit over its members are reminiscent of the living conditions of a big kinship family in ancient times. In this regard, the work unit can be argued to be 'feudalism in a period of industrialisation' (Dutton, 1998, p. 42).

3. Walled enclosure: although there was wide variation among work-unit compounds in 
terms of scale, layout, supplied facilities and social services, and so on, the overwhelmingly ubiquitous presence of walls and guarded gates built along the boundaries of most, if not all, work-unit compounds was the most visible common feature.

Thus, the multifunctional compound built by work units in socialist China became a miniature

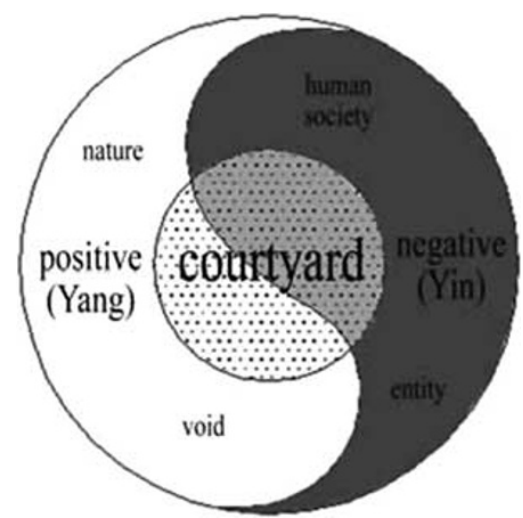

Figure 11: Daoist view of courtyard. city within its own walls, 'somewhat reminiscent of the walled wards of the early traditional Chinese cities' (Gaubatz, 1995).

\section{Re-erected walls of work units and demarcated urban landscape}

Work-unit walls seem inexplicable, especially in such an egalitarian socialist society. But from the analysis above, it is arguably clear that the work unit is actually a kind of 'club', an economic entity for collective production and consumption. Hence, it is inherently exclusive. ${ }^{6}$ In fact, although most work units constructed in the 1950s were originally without walls, many work units started to build permanent walls in the 1960s to protect their land and other resources from encroachment due to uneven development $(\mathrm{Lu}, 2006)$ between not only work units and external urban areas, but also between different work units (Gong and Chen, 1994). Unit walls gradually became the norm and were often the first structure to be built when establishing a new work unit. Eventually,

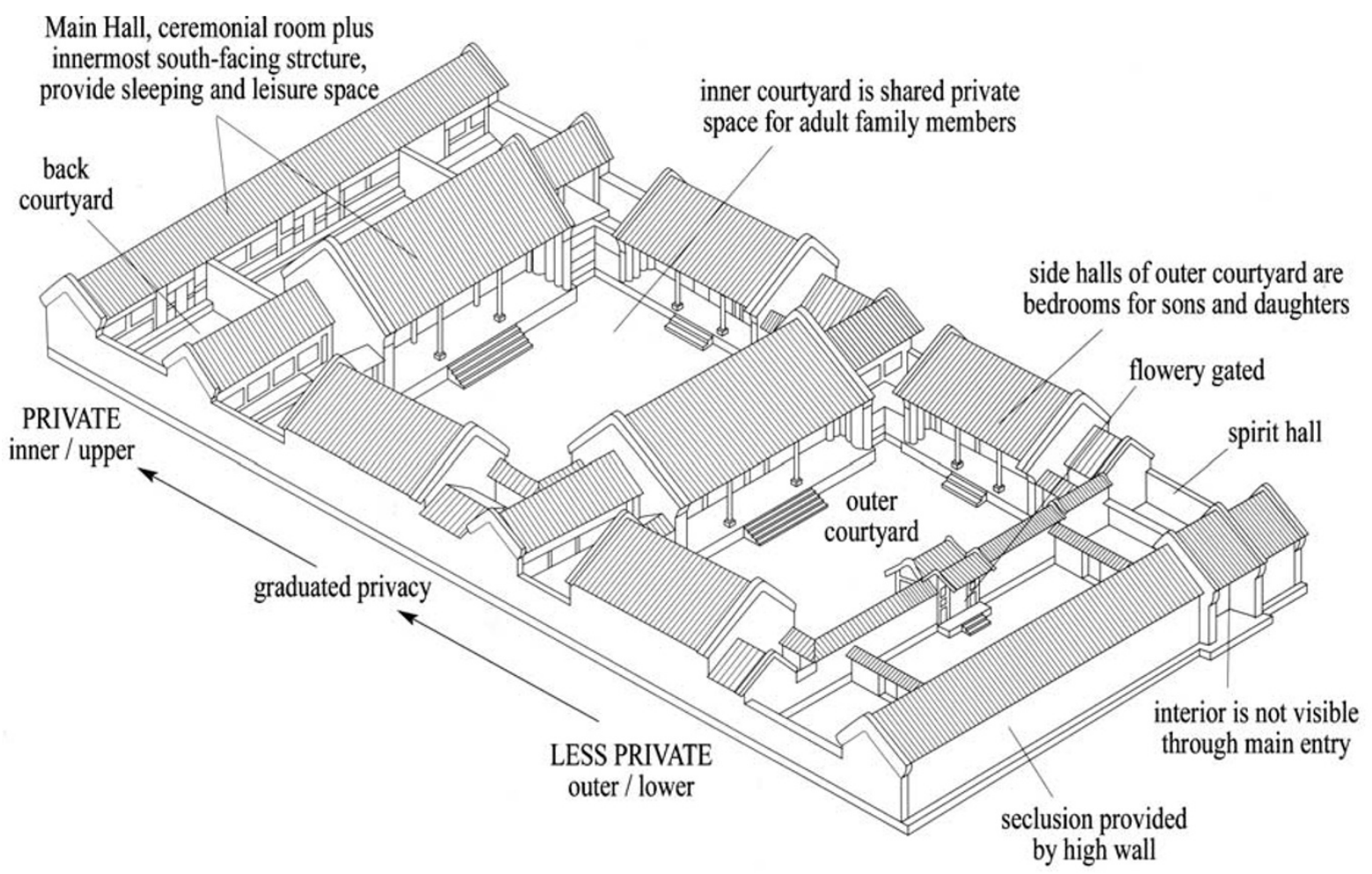

Figure 12: Perspective of a typical complete courtyard house.

Source: Reproduced from Knapp (2005), with the permission of Tuttle Publishing Press. The kinship status of the family members was defined by the location in terms of inner/outer, front/back, upper/lower, left/right and the distance from the central/innermost courtyard. And the transition from the public to the private spaces is skilfully achieved by means of the entrance spatial sequence: the main entry, small reception courtyard, forecourt, outer courtyard, and finally the inner courtyard, the heart of the family compound. 

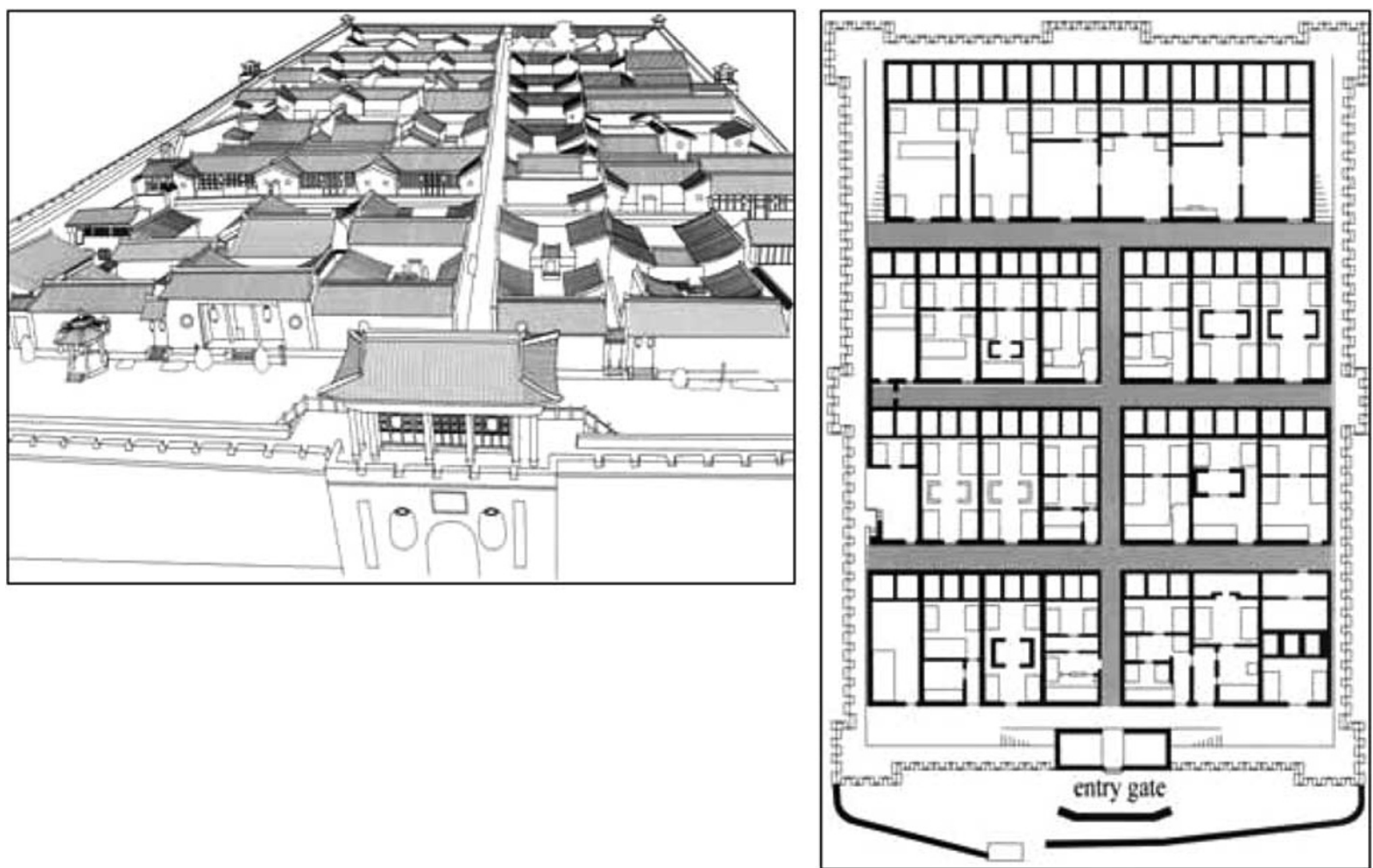

Figure 13: Perspective (left) and ground floor plan (right) of Wang Family, Shang Xi Province. This gated residential compound of 4.5 ha site area consists of 123 courtyards and 1118 rooms.

Source: Reproduced from Knapp (2005), with the permission of Tuttle Publishing Press.

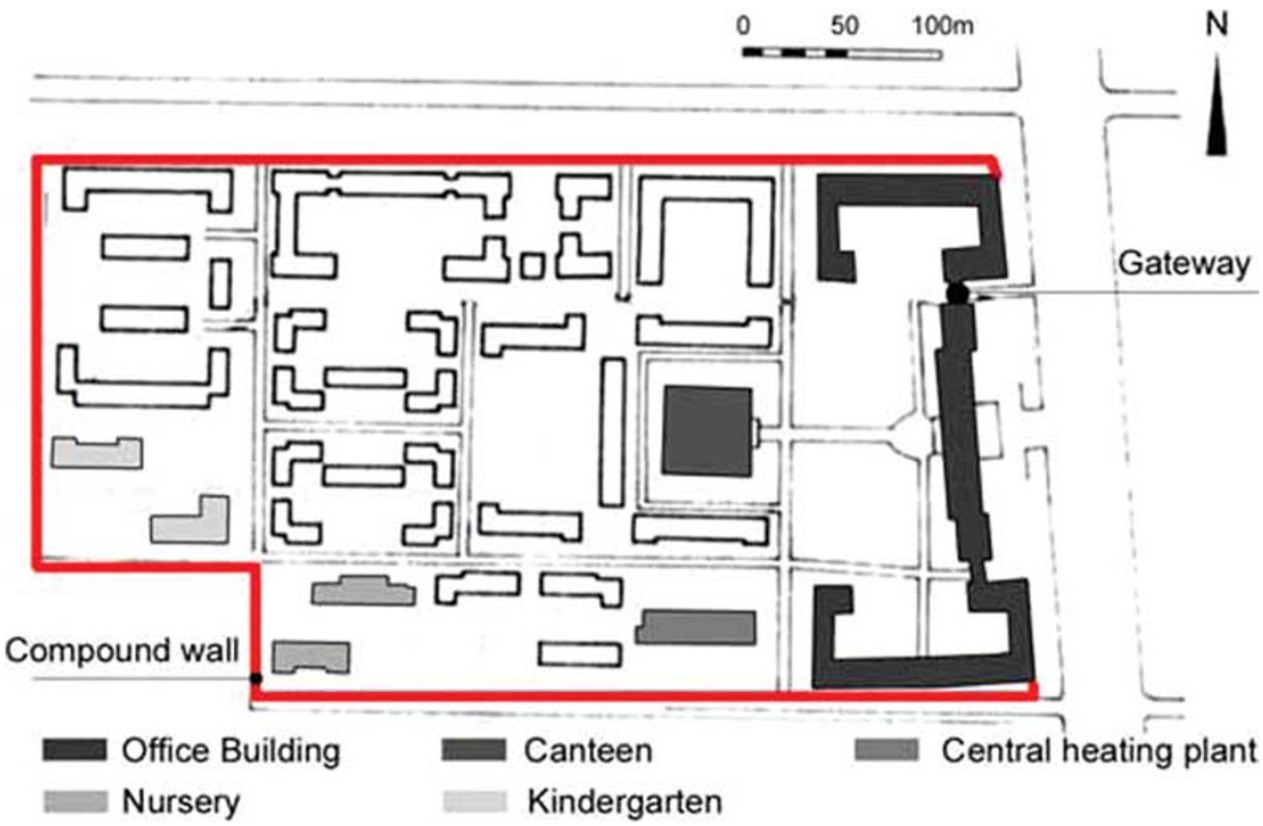

Figure 14: A small-scale walled compound (danwei) with one entrance, Beijing. 
almost every work unit was a walled enclosure or a cluster of several walled enclosures ( $\mathrm{Lu}, 2006)$. The walls, in most cases made of brick, set the work unit physically apart from its surroundings. There were usually several entrances with a small janitor's room at each one. Generally, pedestrian and vehicle access were treated differently.

As for pedestrians, the regulation of accessibility varied from unit to unit and often changed according to the social conditions of the time. But basically, the work unit had the right to enquire about or exclude anyone who was not a regular resident in it. The facilities in each unit, bathhouses for example, were generally for the exclusive use of unit members. The extent of the rigid control also varied from unit to unit and from time to time. In some cases, small units with limited resources cooperated to support the joint use of some facilities such as schools and hospitals. The gate was often closed at midnight and opened in the early morning, because the capitalist night lifestyle was discredited in socialist ideology and fully suppressed at that time. Despite the comparatively loose control of pedestrian access in general, through traffic was not allowed at any time.

The site planning of a work unit was initially carried out by the local Urban Planning Bureau. It mostly focused on location and scale, leaving the detailed layout to the work unit's own Infrastructure Engineering Department. Because of the wall, there was no need for the spatial structure of the work unit to respect the surrounding context. So, rather than integrating with the outer urban structure, the walled compounds generally formed a system of their own with a flexible pattern to fit geographical and functional needs. As a result, China's socialist cities became dominated and demarcated by walled work units, and this urban structure had a fundamental and irreversible impact on the contemporary Chinese urban landscape.

\section{Hybrid Gated Settlements in Transitional Urban China, 1978-Present}

\section{Commodification of urban housing management and the emergence of gated community}

Owing to the minimum investment strategy in the non-productive sector of housing after the founding of PRC, and almost 10 years of stagnation in housing construction during the Cultural Revolution, there was an overwhelming housing shortage and poor living conditions in China at the end of the 1970s. ${ }^{7}$ The rigid housing welfare system, in which urban housing was offered at nominal rent by work units and municipal housing bureaus, became a heavy fiscal burden and an institutional constraint on governmental capacity to improve housing conditions. Therefore, since 1980 when the economic reforms toward a socialist market economy were officially announced, the Chinese government has launched a series of housing reform programmes to tackle this pressing housing deficiency (Fong, 1989; The World Bank, 1992; Wang and Murie, 1996; Yeh and $\mathrm{Wu}, 1$ 1999). A major change in housing reform was that housing benefits would be provided in cash wages rather than in kind. This led to a full-scale national boom in commodity housing markets in the following decades (Chen, 1993; Wu, 1996).

Before reform, a large proportion of the services and maintenance of urban housing was taken over by work units. As for other urban living quarters beyond the work units, the local Department of Housing Bureau would take charge of the maintenance services. This management system imposed huge pressure on local government during the process of market-oriented housing reforms. On the one hand, demand for housing management services soared when the estate management of some of the state-owned work units was transferred to local government during enterprise reform $(\mathrm{Wu}, 2002)$, and when numerous commodity housing projects were completed; on the other hand, local government could hardly satisfy this huge demand, especially when management taxation was still not applicable within the socialist institutional framework, which had not changed simultaneously with economic reform. Therefore, an urgent challenge for housing reform was to find a new pattern of urban housing management within the existing economic and institutional structure.

In the mid-1980s, the first array of property management companies following the model in Hong Kong was established in Shenzhen (Xie, 2006). They collected service fees directly from residents and provided estate management in return. This service was well accepted by urban residents and was gradually introduced to cities throughout the country. It developed rapidly in the fast growing commodity housing market, especially after the central government legitimated property management services in the 
'Measure for the Management of Newly Constructed Residential Areas in Cities' issued in 1994. From the residents' perspective, it is natural for those who pay the maintenance fees to regard the whole area as their private property. Thus, it is rational for the residents of gated communities to be aware of the free-rider problem, and of the potential harm to their property rights and values due to unpredictable environmental deterioration in an era of fast urban development, and to take measures to prevent it. From the perspective of property management companies, it is much more convenient for them to demarcate the area to make clear the responsibilities of management. So, enclosed residential developments were soon seen in China after specialized estate management companies took over the maintenance of commodity housing. As a result, these gated residential developments managed by specialized agencies reproduced the exclusive feature of the Chinese work units, and presented arguably the strongest echo of the global phenomenon of the 'gated community'.

\section{Diversified gated communities in contemporary China and concerns on both sides of boundaries}

Gated community has gained such unprecedented popularity that it has become the dominant development pattern in the commodity housing market, as it has been widely adapted to upper-, middle- and lower-market production by means of the variation of service fees. More and more urban residents of very different backgrounds have moved from types of pre-1949 traditional urban block and work-unit settlements to gated community-type settlements. Most gated communities are initially located in newly developing suburban areas, but many have been rapidly integrated into a local centre due to the fast expansion of urbanization. Meanwhile, there are still a few gated communities being built in inner urban areas as brown-field redevelopments. When widely adapted within the complicated social, economic and environmental urban contexts throughout the country, gated communities in China present highly diversified social, organizational and spatial characteristics. First of all, the territorial and social scales of developments have varied project by project, from just a group of two or three apartment buildings in a small plot aiming at specialized end-users, to a large residential district of over 100 ha (Figure 15), comprising high-, mid- and low-rise building types and targeting clients with very different income levels. The enclosed communal amenities, facilities and services provided therefore vary correspondingly. Secondly, the boundaries of gated communities are not confined to walls or to natural and man-made fences. In many cases, especially in dense urban areas with flourishing urban life, mixed-use buildings facing streets are built up as boundaries. Unlike walls and fences, they support diverse uses and activities along streets besides functioning as a means of separation. Finally, the extent of control and exclusion also varies greatly across different gated communities and is even changing over time with respect to the surrounding environmental conditions (Figure 16).

There is a common interest for nearly all gated communities, that is, the quality of the collective shared internal open space. As medium- or highrise apartments are the major building type of gated communities in China, there are 120-180 households per hectare in general (Miao, 2003). Except for a few luxury gated communities of villas, a private garden is generally not available in such a high density form (Figure 17). The shared open spaces in gated communities, the landscape and the facilities, are de facto valuable green spaces for the small niche of the housing development, and the foci of the residents' daily outdoor activities. Thus, shared open space is viewed as an indispensable part of housing quality and property value, demanding elaborate design, construction and management.

However, this intensive interest in the internal environment does not, like gated communities in American cities, displace the concerns that residents of gated communities have for the external public environment. High density as the common feature of Chinese cities causes gated communities to exist nearby or even be interwoven with their surroundings. Moreover, despite soaring private car ownership in China, a majority of residents in gated communities still rely heavily on public transport (Miao, 2003) in the spaces outside their enclosures. As a result, the quality of the environment outside gated communities is still a major concern of the residents in gated communities.

\section{Persistent work-unit walls and spatial entities in the post-socialist era}

After 20 years of reform, China currently has a dual system of housing sectors: privatized public 


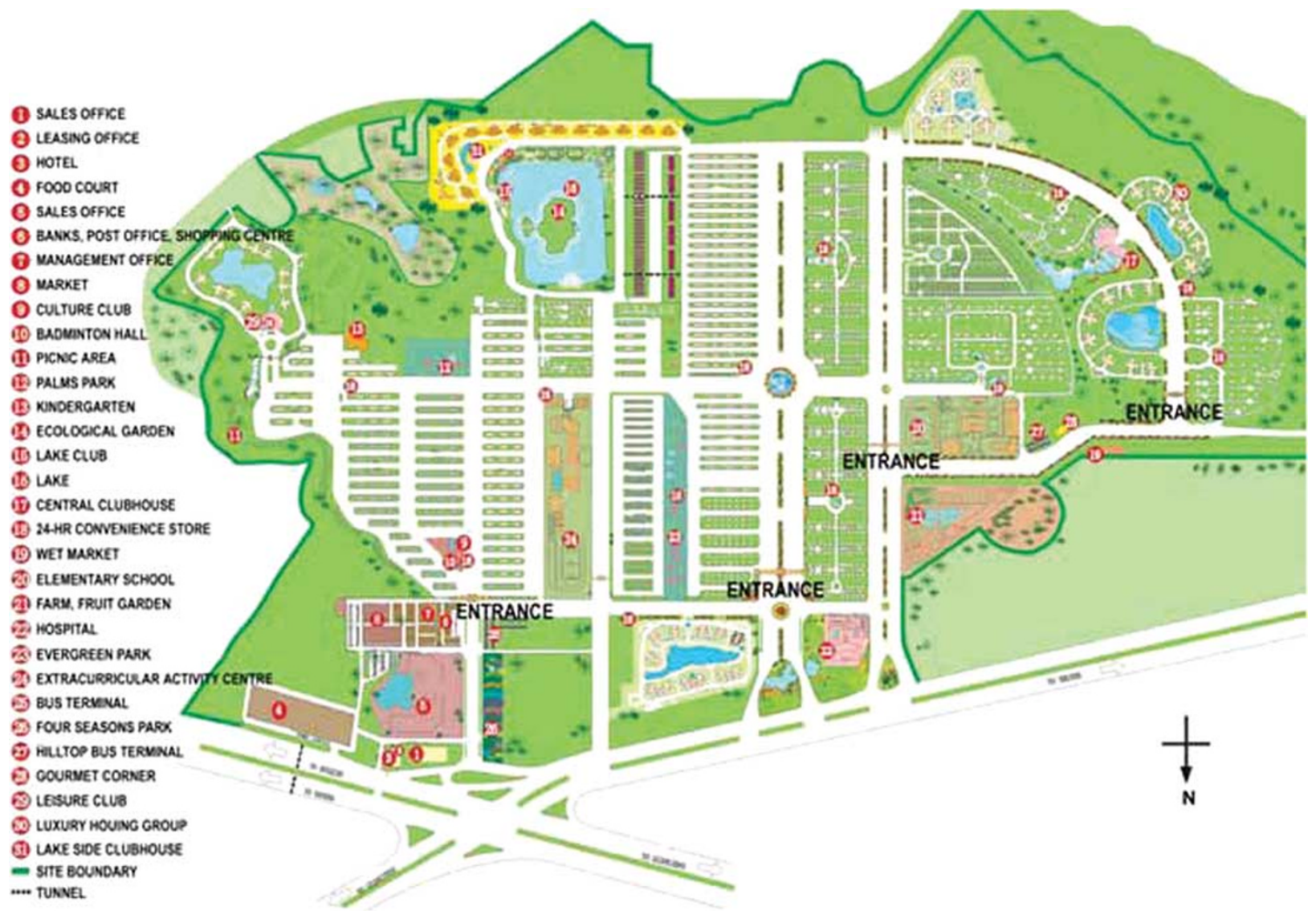

Figure 15: Site plan of a large-scale gated community in Guangzhou. It has 433.55 ha enclosed area and 70000 permanent residents.

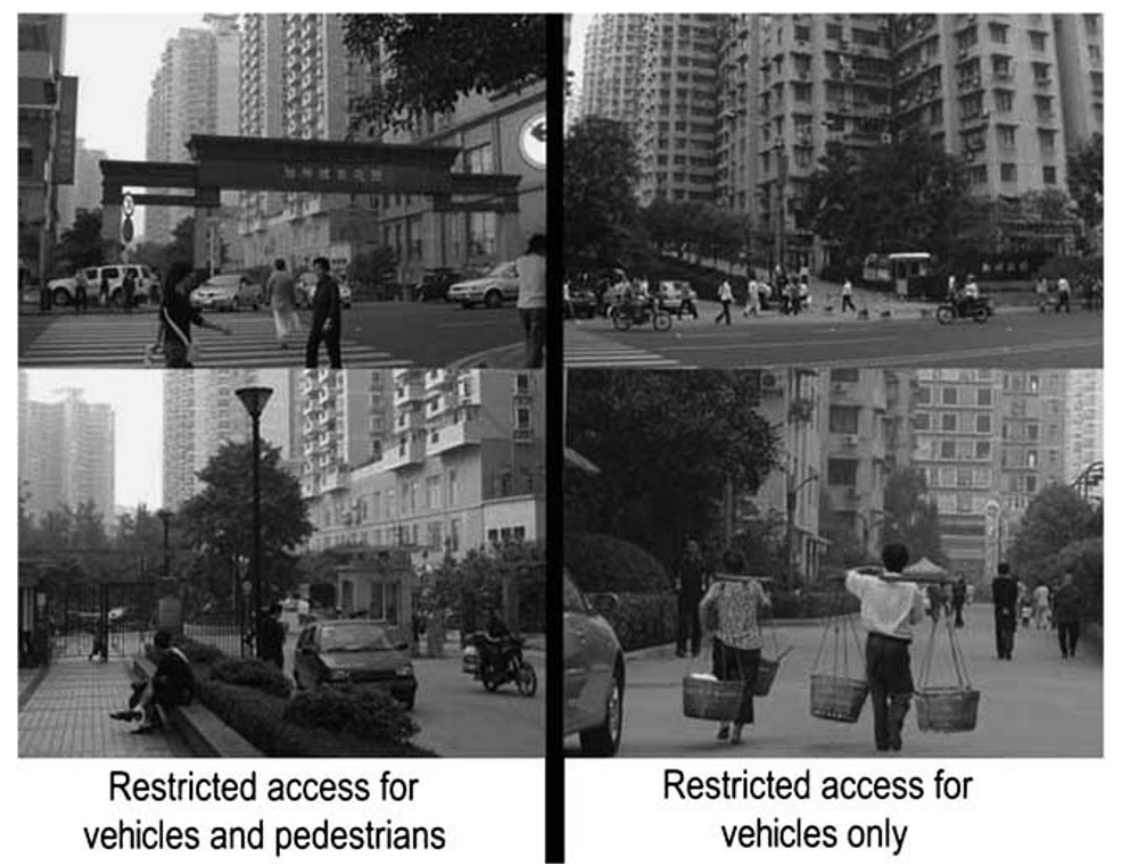

Figure 16: Varied conditions in terms of accessibility. The two gated communities shown in the left and right photos respectively are sitting opposite along a local public street in Chongqing. Although developed with similar density, building type and facilities, they apply different regulations on accessibility. 
housing ${ }^{8}$ and commodity housing with different prices, rents and delivery patterns (Chiu, 2001; Zhang, 2001). Rosen and Ross (2000) argue that the resale of privatized public housing is not feasible because the owners of such housing still rely on their work units for maintenance and improvements. Meanwhile, work units are reno-

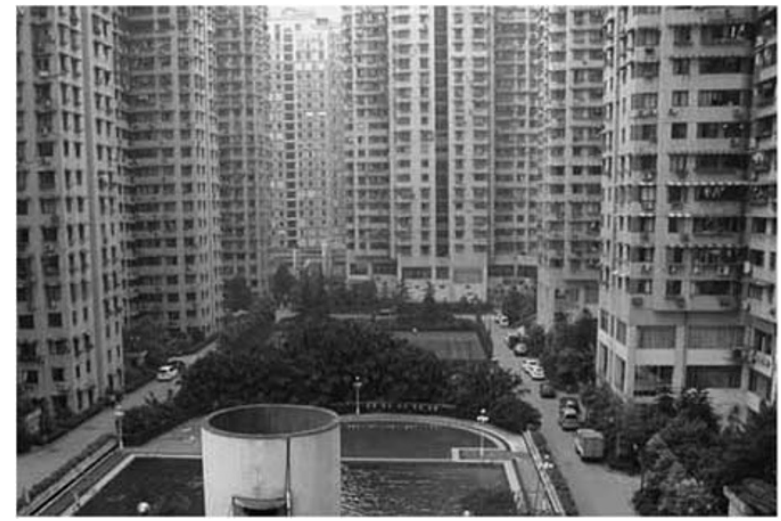

Figure 17: Shared open spaces in dense urban form. vating old houses and constructing new ones, so as to provide their employees with up-to-date and improved housing conditions. As a result, owning

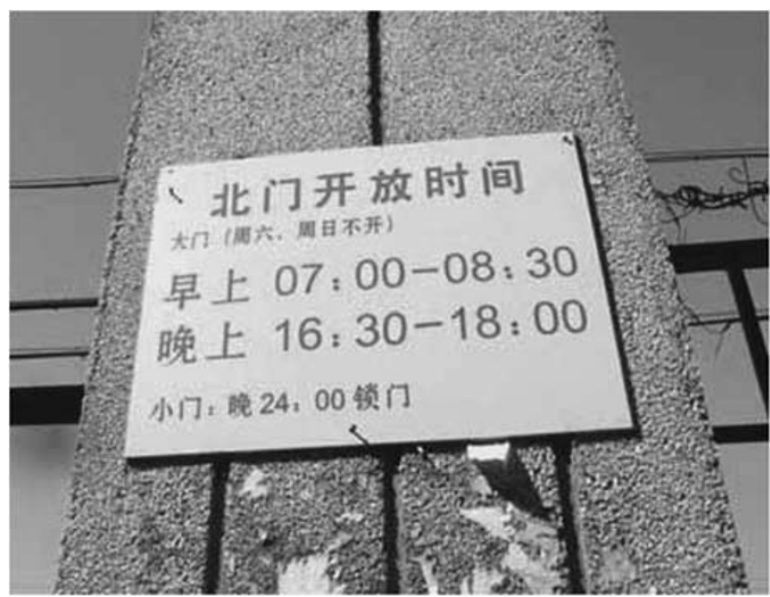

Figure 19: Notification board at gateway. It states the opening times of this gate: 'the gate for vehicles is only opened during weekdays, from 07:00 to 08:30 in the morning and from 16:30 to 18:00 in the afternoon; the gate for pedestrian is opened every day but closed at midnight'.

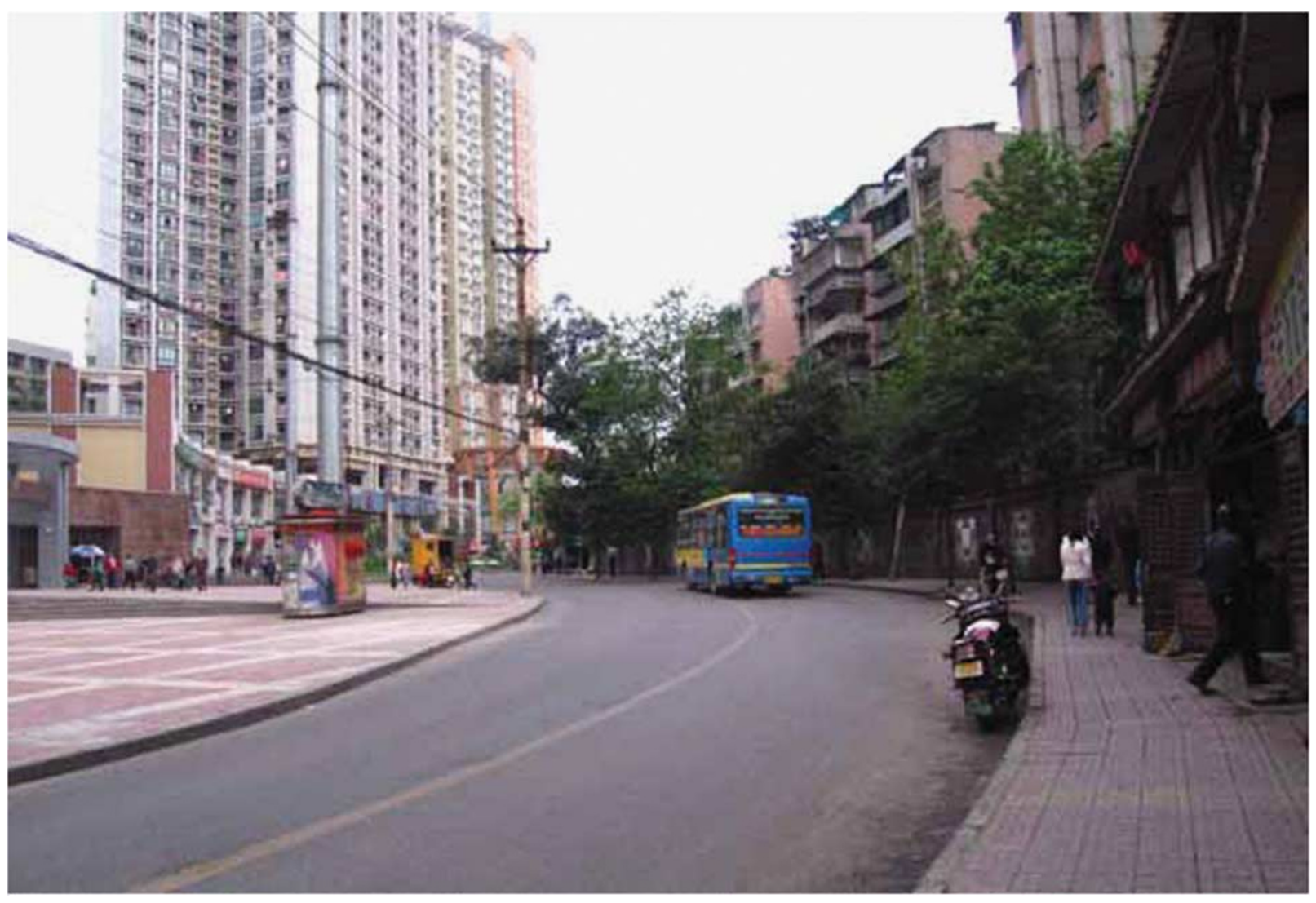

Figure 18: Juxtaposition of gated commodity housing development (left) and walled work-unit residence (right) along a local road of Chongqing. While the boundary for the gated development is developed into two-storey buildings for commercial uses, a small part of the work unit wall is also replaced with rentable buildings facing outside. 


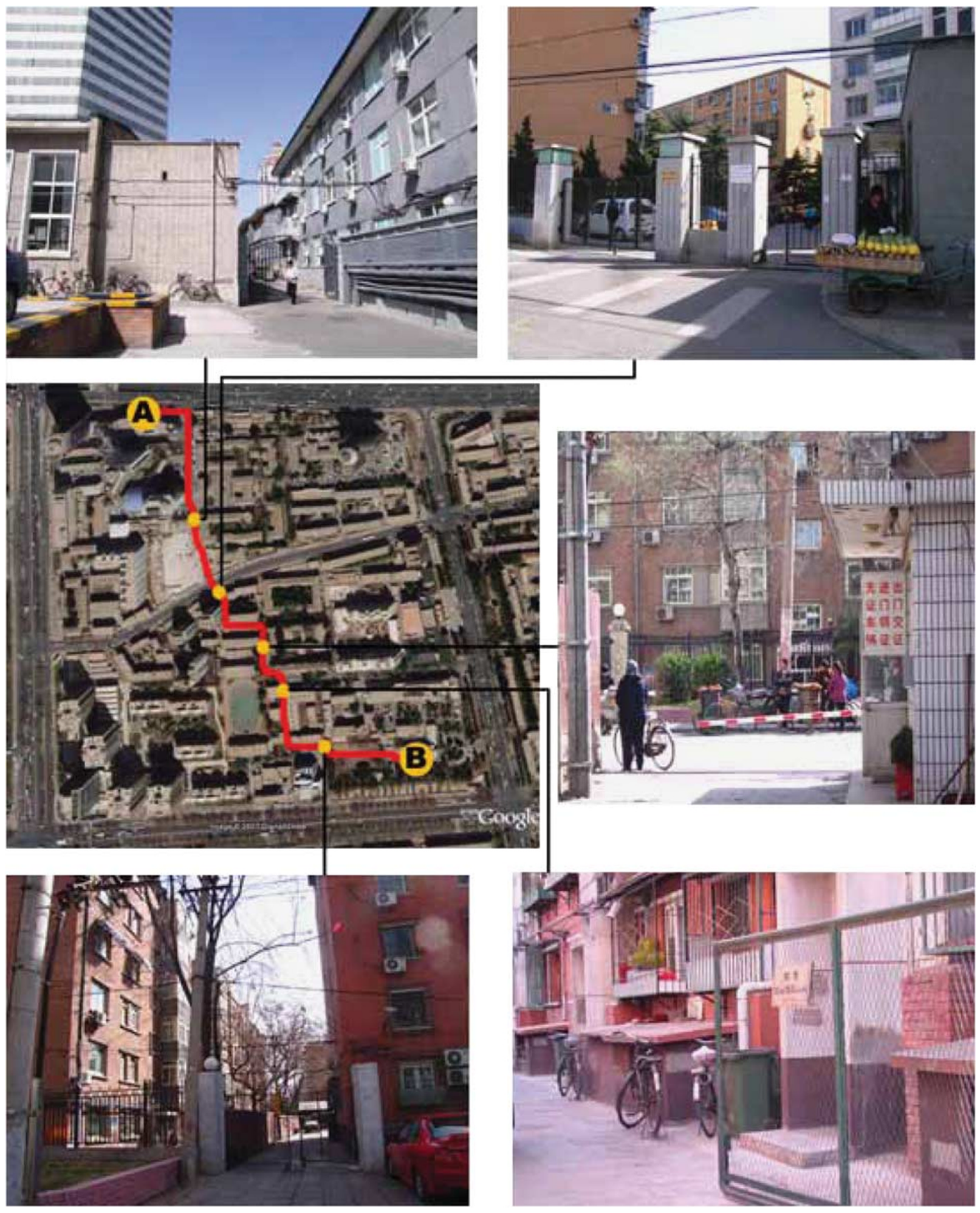

Figure 20: Five gates along a shortcut between spot A and sport B in an urban area of Beijing, which is dominated by walled workunits. Only the local residents know this route and the opening times of these gates well. For a stranger, the only way from A to B is to follow the arterial road. 
a large stock of land and housing resources, work units are still regarded as playing a key role in the urban housing sector ( $\mathrm{Fu}$ et al, 2000; Li, 2000; Zhu, 2000; Li and Siu, 2001; Zhao and Bourassa, 2003; Zhang, 2006). Along with soaring land prices in the market-oriented economy, occupied lands were viewed as important assets of the work unit. In this case, the walls of the work unit have been well preserved rather than demolished, although today work units' control of their employees' everyday lives has been greatly weakened. In urban areas with prosperous businesses, some walls have been replaced by outward-facing buildings, which continue to separate the outside from the inside (Figure 18).

Although the boundary remains, management has become much flexible in response to the increasingly rich and colourful urban life of the post-socialist era. More gates have been set up in the walls around work units to improve access to the outer world for the sake of residents' convenience. Generally, all the gates are open in the daytime and provide free access for outsiders by foot or bicycle, while some are required to be closed at night by the residents in the work unit for security reasons (Figure 19). These walls and gates by and large do not bother local people, who are familiar with all these gates and their opening hours. Nevertheless, they still function as barriers for strangers, preventing them from getting through walled areas, and therefore greatly decrease the accessibility of the area. For vehicles that do not belong to the work unit or employees and their family members, a through traffic fee would normally be charged. Obviously, the road system of the work unit is still not integrated into the whole road network of the city (Figure 20).

\section{Conclusion}

Gated residential development has a long history in China. It can be dated back to the walled cities including fortress-like palaces for the gentry and enclosed courtyard housing for ordinary people in ancient times, through to the enclosed workunit compounds of the socialist era. Two features are remarkable for this morphological continuity in the analysis. One is the culture of collective living with a territorial control. It proves persistent by the courtyard-style family housing complex, its adaptation in colonist time, the work-unit compound and gated community, though the bonding relationships are based on family/kinship, territory-based community, fellowship and the business contract respectively. The other is the introverted housing compound with buildings and walls deployed around the communal outdoor spaces. This kind of spatial arrangement can be ubiquitously found in Chinese urban settlements of all ages. Apart from persistence, these two features also demonstrate their great adaptability, as they were widely adopted in ancient urban fabrics, westernized cities at treaty ports in colonial times, socialist work-unit compounds and diverse gated communities today, on greatly varied scales. With a capacity to renew itself, the ingrained tradition of gated residence is malleable enough to enable old ways of living to operate in new contexts in a new era. This, on the one hand, provides a contextual interpretation for the unexpected popularity of gated community in China; on the other hand, it elucidates that historical and cultural legacies have a deep impact on the features of gated communities in China today.

Notwithstanding the obvious continuity of the introverted spatial form, the current gated community in China is quite different from all its predecessors with respect to design strategies, development processes and/or physical outcomes. First, by and large, the enclosure size varies greatly in all enclosed residential settlements in history, but with differentiated determinants behind in design practices. The enclosure size of traditional courtyard housing, including the colonist adaptation (hereafter), and work-unit compounds was up to their own decisions in consideration of the included members and organizational scale. In contrast, gated communities in China today are generally stipulated by a local land subdivision plan but often negotiable in the development process with respect to the development and marketing strategies. Second, it can be observed from the functionally various boundaries that the boundaries of gated communities in China today have been consciously designed and developed according to the market needs by means of a package-development. In contrast, those of work-unit compounds and traditional courtyard houses were mostly developed as walls or fences with the single function of spatial demarcation, while some frontages of traditional houses along commercially prosperous streets were often transferred into shops over time in a bottom-up and piecemeal development style. Last but not least, while courtyard housing 
completely depended on daily supply from outside the enclosure, the work unit tended to develop into a self-sufficient settlement. As regards gated community of today, the internal facilities and the provision strategies vary greatly among different developments targeting at different client groups.

It can be argued that smaller enclosure size means more accessibility for local streets; the more diverse uses the boundaries can support, the more activities on the immediately surrounding streets; and the fewer the internal facilities, the greater the reliance on supply from the neighbouring streets. These three aspects actually determine the relationships between enclaves and their neighbouring public spaces. The above analysis shows that compared to courtyard housing and work units, gated communities in China today oriented by market economy show awareness and a conscious manipulation of this relationship, no matter whether positively or negatively, by means of design.

Therefore, there are arguably two implications from the analysis of the design history of China's gated cities and neighbourhoods. One is that based on China's experience, although the spatial forms of all gated communities present an universal similarity in terms of the general 'fortress' like image, detailed physical features of gated communities, which are possibly of greater significance in people's everyday life, may vary a lot across nations to fit the very specific urban context. These physical features include morphological elements, transit stops, community and commercial facilities and amenities. The other is that though deeply ingrained in Chinese housing tradition and the history of urban design, gated community in China today is economic-sensitive and by no means a continuation of its history predecessors such as walled low-rise courtyard houses or enclosed work-unit compounds. The evolving trajectory of gated community since the market-oriented housing reform was kicked off in 1980s shows that rather than any historical or cultural factor, the public/governmental retreatment in housing provision and management is de facto the foremost driving force bolstering the contemporary revival of gated residential quarters in post-reform China. In sum, gated community in contemporary China has engaged various socio-cultural, economic, institutional and environmental factors, presenting a tangled picture in terms of development process and final physical outcome.

\section{Acknowledgement}

Many thanks to Professor John Punter for his encouragement and valuable advice.

\section{Notes}

1 'We call urban design the symbolic attempt to express an accepted urban meaning in certain urban forms' (Castells, 1983, p. 304).

2 Tang Chang'an had a profound impact not only on Chinese ancient cities but also on those in North Asian countries such as Korea and Japan.

3 In ancient Chinese, $l i$ referred to an enclosed area for a certain community commonly consisting of about 25-100 dwelling units, while $l \ddot{u}$ meant the gate of this compound.

4 'We put 30 spokes together and call it a wheel; but it is on the space where there is nothing that the usefulness of the wheel depends. We turn clay to make a vessel; but it is on the space where there is nothing that the usefulness of the vessel depends. We pierce doors and widows to make a house; and it is on these spaces where there is nothing that the usefulness of the house depends' (The Dao De Jing, a sixth-century bc work attributed to Laozi).

5 In the drier and colder areas of north and north-eastern China, courtyards are broader and occupy more generous proportions, increasing the receipt of sunshine and blocking the cold winter winds by virtue of the surrounding buildings and walls. In the south, where winters are mild and summers hot, courtyards shrink greatly in size and generally decrease in proportion, functioning as ventilation of interior spaces while blocking sunlight from penetrating the buildings.

6 Club goods (also known as collective goods) are a type of good in economics, sometimes classified as a subtype of public goods that are excludable but non-rivalrous, at least until reaching a point where congestion occurs (Buchanan, 1965).

7 According to 1978 statistics released by the Ministry of Construction, in 182 cities throughout the country, per capita floor space had declined from 4.5 square metres in 1952 to 3.6 square metres.

8 The privatized public housing system is the system that has been in operation in various work units including official departments, universities, institutions, and so on. Residents buy or rent their property at a preferential price, but they do not have full property rights, as the work unit owns the land.

\section{References}

Atkinson, R. and Blandy, S. (2005) Introduction: International Perspectives on The New Enclavism and the Rise of Gated Communities. Housing Studies 20(2): 177-186.

Bater, J.H. (1980) The Soviet City. London: Edward Arnold.

Blakely, E.J. and Snyder, M.G. (1997) Fortress America: Gated Communities in the United States. Washington, D.C.: Brookings Institution Press.

Buchanan, J. (1965) An economic theory of clubs. Economica 32(February): 1-14. 
Cartier, C. (2005) City-space: Scale relations and China's spatial administrative hierarchy. In: L.J.C. Ma and F. Wu (eds.) Restructuring the Chinese Cities: Changing Society, Economy and Space. Abingdon, UK: Routledge, pp. 21-38.

Castells, M. (1983) The City and the Grassroots: A Cross-cultural Theory of Urban Social Movements. London: Edward Arnold.

Chen, X. (1993) Urban economic reform and public housing investment in China. Urban Affairs Quarterly 29: 117-145.

Chiu, R.L.H. (2001) Commodification of housing with Chinese characteristics. Review of Policy Research 18(1): 75-95.

Cuthbert, A.R. (2005) A debate from down-under: Special political economy and urban design. Urban Design International 10: 223-234.

Dong, J. (2004) History of Chinese Urban Construction, 3rd edn. Beijing, People's Republic of China: Zhongguo Jianzhu Gongye Press

Dutton, M. (1998) Streetlife China. Cambridge, New York: Cambridge University Press.

Fong, P.K.W. (1989) Housing reforms in China. Habitat International 13(4): 29-41.

Frantz, K. (2001) Gated communities in Metro Phoenix (Arizona): A new trend in the US-American urban development. Geographische Rundschau 53: 12-18.

Fu, Y., Tse, D. and Zhou, N. (2000) Housing choice behavior of urban workers in China's transition to a housing market. Journal of Urban Economics 47: 61-87.

Gaubatz, P. (1995) Urban transformation in post-Mao China: Impacts of the reform era on China's urban form. In: D. Davis (ed.) Urban Spaces in Contemporary China. Cambridge: Cambridge University Press, pp. 28-60.

Glasze, G. (2005) Some reflections on the economic and political organisation of private neighbourhoods. Housing Studies 20(2): 221-233 (13).

Gong, T. and Chen, F. (1994) Institutional reorganisation and its impact on decentralisation. In H. Jia and Z. Tin (eds.) Changing Central-Local Relations in China: Reform and State Capacity. Boulder, CO: Westview Press, pp. 67-88.

$\mathrm{Gu}, \mathrm{K}$. (2001) Urban morphology of China in the post-socialist age: Towards a framework for analysis. URBAN DESIGN International 6: 125-142.

Heng, C.K. (1999) Cities of Aristocrats and Bureaucrats: The Development of Medieval Chinese Cityscapes. Hawaii: University of Hawaii Press.

Huang, Y. (2006) Collectivism, political control and gating in Chinese cities. Urban Geography 27(6): 507-525.

Huang, Y. and Low, S. (2007) Is gating always exclusive? A comparative study of gated communities in American and Chinese cities. In J.R. Logan (ed.) Urban China in Transition. Oxford: Wiley, Blackwell.

Knapp, R.G. (2005) Chinese Houses: The Architectural Heritage of a Nation. Singapore: Tuttle.

Li, S. (2000) Housing consumption in urban China: A comparative study of Beijing and Guangzhou. Environment and Planning A 3232: 1134-1165.

$\mathrm{Li}, \mathrm{S}$. and Siu, Y. (2001) Residential mobility and urban restructuring under market transition: A study of Guangzhou, China. Professional Geographer 53: 219-229.
Liu, D. (1984) History of Chinese Historical Architecture, 2nd edn. Beijing, People's Republic of China: Zhongguo Jianzhu Gongye Press.

Low, S. (2003) Behind the Gates: Life, Security and the Pursuit of Happiness in Fortress America. New York: Routledge.

Low, S. (2006) How private interest take over public space: zoning, taxes, and incorporation of gated communities. In: Low, S. and Smith, N. (eds.). The Politics of Public Space. New York: Routledge, pp. 81-103.

Lu, D. (2006) Remaking Chinese Urban Form: Modernity, Scarcity and Space, 1949-2005. London, New York: Routledge.

Miao, P. (2003) Deserted streets in a jammed town: The gated community in Chinese cities and its solution. Journal of Urban Design 8(1): 45-66.

Rosen, K. and Ross, M. (2000) Increasing home ownership in urban China: Note on the problem of affordability. Housing Studies 15: 77-89.

The World Bank (1992) China: Implementation Options for Urban Housing Reform. Washington DC: The World Bank.

Wang, Y. and Murie, A. (1996) The process of commercialisation of urban housing in China. Urban Studies 33(6): 971-989.

Webster, C. (2001) Gated cities of to-morrow. Town Planning Review 72(2): 149-169.

Webster, C. (2002) Property rights and the public realm: gates, green belts, and Gemeinschaft. Environment and Planning B: Planning and Design 29(3): 397-412.

$\mathrm{Wu}, \mathrm{F}$. (1996) Changes in the structure of public housing provision in urban China. Urban Studies 33(9): 1601-1627.

$\mathrm{Wu}, \mathrm{F}$. (2002) China's changing urban governance in the transition towards a more market-oriented economy. Urban Studies 39(7): 1071-1093.

$\mathrm{Wu}, \mathrm{F}$. (2005) Rediscovering the 'Gate' under market transition: From work-unit compounds to commodity housing enclaves. Housing Studies 20(2): 235-254.

$\mathrm{Wu}$, J. (1993) The historical development of Chinese urban morphology. Planning Perspectives 8: 21-52.

Wu, N.I. (1963) Chinese and Indian Architecture: The City of Man, The Mountain of God and The Realm of The Immortals. London, New York: Prentice-Hall; Braziller.

Xie, J. (2006) The status quo of property management in China and the pressing issues (in Chinese), http://old.cin.gov.cn/ indus/speech/2001072003.htm.

Yeh, A.G.O. and Wu, F. (1999) The Transformation of the Urban Planning System in China from a Centrally Planned to Transitional Economy. Oxford, UK: Pergamon.

Zhang, X. (2001) Risk and uncertainty in the Chinese housing market. Journal of Real Estate Literature 9: 161-173.

Zhang, X. (2006) Institutional transformation and mercerisation: The changing patterns of housing investment in urban China. Habitat International 30: 327-341.

Zhao, Y. and Bourassa, S.C. (2003) China's urban housing reform: Recent achievements and new inequities. Housing Studies 18(5): 721-744.

Zhu, J. (2000) The changing model of housing provision in transitional China. Urban Affairs Review 35: 502-519. 